tion can to-day only be found in isolated groups in the hills : at least three migrations from the north having at various times overrun the land. It was but a few centuries ago that a number of petty kingdoms arose, and only comparatively recently that what can be called a*real national feeling has developed. Siam is a country little known to the average white man. It merits somewhat more detailed treatment than has been possible in these 18 pages. The illustrations, once again, are delightful.

\section{Work of the Tennessee Valley Authority}

THE article "T.V.A. An Achievement of Democratic Planning", by Dr. Julian Huxley, which occupies the greater part of the June number of The Architectural Review, should be of wide interest in view of the absence in Britain of adequate descriptions of the work of the Tennessee Valley Authority. This concise but comprehensive account of T.V.A. in all its implications, which is illustrated by many photographs, most of them new, gives a striking demonstration of the possibilities of judiciously and democratically applied regional planning. The article is timely, for in the post-war planning which must be undertaken in Great Britain we cannot afford to neglect the experience gained in ten years work on the world's boldest venture in regional reconstruction. Moreover, Dr. Huxley includes a critical examination of the limiting conditions of such democratic planning and stresses the essential characteristics : the making of the greatest number of decisions on the spot; development so far as possible of the active participation of the people themselves; co-ordination in the field of the work of all the other agencies concerned; and decentralization of the idea behind an administration so that its planning becomes a part of public opinion. The provision of full powers for a limited function with the organization developed, and the special methods of survey and system of research deliberately adjusted to consumer needs, are all new tools, as Dr. Huxley points out, which will be of service to any democracy in its struggle to control its own social destiny.

Scientific workers will be particularly interested in Dr. Huxley's concise account of research carried out by the Tennessee Valley Authority. In its chemical laboratories a method has been worked out for extracting aluminium from certain common types of clay, which has reached the pilot plant stage, and work on the extraction of magnesium from olivine is also coming to the pilot stage. In the biological field, valuable research has been carried out on malaria control, the incidence of malaria and the encouragement of fish life. The most important aspect of its agricultural research is concerned with the prevention of erosion, including the growing of new cover-crops, while the investigation devoted to the perfecting of agricultural machinery is an excellent example of research carried out and applied from the point of view of consumer interests. This has led, for example, to an electric hay-drier, costing less than 10 per cent of the previous cheapest drier on the. market, and a cheap furrow seeder. Elaborate experiments have been conducted to discover suitable trees and shrubs which will yield crops of fruit or nuts suitable for direct human consumption or available for pigs or other animal stock. Much research has been put into the development of a new type of pressure-cooker for producing cottonseed meal and oil. Other research has led to the development of quick-freezing machinery suitable for use by farmers' co-operatives, which has much increased the growing of various fruit crops. The planned surveys of the Authority are of equal interest, and a new type of land classification has been worked out with the co-operation of the National Resources Planning Board; and a land-use survey has also been prepared for the most important areas of the Tennessee Valley.

\section{Aid for Chinese University Students}

The International Student Service Committee in Chungking is a constituent member of the National Student Relief Committee, which works in close cooperation with the Chinese Government and enjoys the full support of the United Aid to China Fund in Great Britain. Among other schemes, the National Student Relief Committee has organized a system of national scholarships, under which two hundred select students receive free maintenance, university education and constant tuition. The International Student Service Committee in Chungking has made itself specially responsible for the creation of a student centre at Shapingba, near Chungking, for refugee students from the occupied zones, and from all parts of Free China. A large percentage of them is homeless and penniless; others receive small grants for food, books, clothes and university fees. A wellstocked library is maintained for them; discussion groups are run on many subjects, including economics, diplomacy and current international topics.

The International Student Service in Great Britain (11D, Regent Street, London, S.W.1) has during past years sent out regular appeals in aid of the universities of China. It has been able to send out more than $£ 1,000$ annually, and hopes to be able to continue this assistance. Any amount collected is now being passed on to the United Aid to China Fund, which has promised to transfer the donations and to make racommendations to Madame Chiang Kai Chek, in whose hands lies the allocation of funds in China. Further information concerning its activities in this connexion can be obtained from the Secretary of the Service, at the above address.

\section{Protection from $\mathrm{X}$-rays and Radium}

THE revised edition of the recommendations of the British X.Ray and Radium Protection Committee (32 Welbeck Street, London, W.1) embodies no drastic changes from the previous issue of this report. Certain precautions have been made more precise, and data relating to more powerful $\mathrm{X}$-ray apparatus and larger quantities of radium used as mass units have been included. Thanks to these recommenda. tions, the extension of irradiation methods into industrial practice should not be followed by an increase in the band of X-ray martyrs who suffered during the early years of the introduction of these methods into medicine. Attention is directed in the report to special Defence Regulations relating to the precautions to be observed by all those engaged in painting objects with radioactive fluorescent mixtures. Although reference is made to the desirability of systematic blood-tests and the measurement of the concentration of radon in expired air, it is strange that no recommendation is made for the periodical inspection of the hands of persons habitually engaged in the manipulation of radioactive prepara. tions or containers. Another apparent omission is the 
neglect to direct attention to the dangers attending the surgical use of diathermy apparatus in the presence of ether vapour. The thanks of all workers in the field of radiology throughout the world are due to the British X-Ray and Radium Protection Ccmmittee for its pioneer and continuing labours in this field.

\section{Vitamin C Content of Oranges}

IN the issue of the New England Journal of Medicine of January 7, Dr. Arthur D. Holmes, James A. Patch and Francis Tripp of the Research Laboratories of E. L. Patch Co., Stoneham, Mass., record their observations on the relation of season, weight and price to the vitamin $\mathrm{C}$ content of oranges. They found that there was considerable seasonal influence on nutritive value, the oranges being heavier and containing more juice at a lower vitamin $\mathrm{C}$ cost in December than at any other seasons, of the year. The cost of $75 \mathrm{mgm}$. was 4.8 cents in March, 5.9 cents in June and September and $3 \cdot 6$ cents in December. The average purchaser, therefore, cannot use the size or cost of oranges as a reliable guide to the amount of juice or to the cost of the daily requirements of vitamin $\mathrm{C}$.

\section{New Zealand Earthquakes}

DURING March 1943, fifteen strong earthquakes were registered by the seismographs at Auckland, Arapuni, Bunnythorpe, Christchurch, Kaimata, New Plymouth, Tuai and Wellington, all stations participating in the New Zealand Seismolrgical Service and sending records or readings to the Dominion Observatory at Wellington (New Zealand Seismological Report-Provisional Bulletin, No. P 133, 1943, March). The records are remarkable in that eight of the shocks had a depth of focus greater than normal. The first, on March 4, had an epicentre south of Fiji and a depth of focus near $600 \mathrm{~km}$. The shock of March 11 with epicentre east of New Caledonia had a depth of focus near $100 \mathrm{~km}$. Earthquakes on March 15 and 21 have already been reported in Nature, the data coming from the U.S. Coast and Geodetic Survey. On March 26 a very strong earthquake with an epicentre south-east cf Tonga had a focal depth of between 80 and $100 \mathrm{~km}$. It was reported to have been felt at Nukualofs, according to a message from Apia. The earthquake gave very large amplitudes on the vertical ccmponents of seismographs. Further, there was minor seismic activity, and 22 earthquakes or earth tremors were reported as having been felt (additionally) in $\mathrm{N} \in \mathrm{w}$ Zealand. The greatest of these shocks was Scale VI on the Modified Mercalli Scale. It occurred on March 14 and was felt in the southern part of South Island. Two earthquakes were felt with Scale V intensity. The first, on March 1, was felt from Te Kuiti and Waipawa to Greymouth and Rakaia. 'The second, on March 25, was felt at Westport. One shcck was felt with Scale IV intensity and the rest with lesser intensities.

\section{Earth Tremors in Portugal}

EARTH tremors accompanied by earthquake noises were reported from Oporto, Braga and Viana do Costelo in north Portugal to have taken place on the night of June 22. Although these tremors caused some apprehension, they did not last long and no serious damage has been reported.

\section{Centenary of the S.S. Great Britain}

ON July 19, 1843, in the presence of the Prince Consort, the famous Great Britain was floated in the dock at Bristol in which she had been under construction for four years. As the first iron ship built for the Atlantic traffic, as the first ocean-going screw ship, and as by far the largest iron ship built up to that time, she stands out as a magnificent specimen of the art of shipbuilding as carried out by farsighted, energetic and unprejudiced men. She was $322 \mathrm{ft}$. long, $50 \frac{1}{2} \mathrm{ft}$. wide and at a draught of $18 \mathrm{ft}$. had a displacement of 3,618 tons. The credit for her construction belongs to Captain Christopher C'laxton, R.N., secretary of the Great Western Steamship Co., the famous engineer I. K. Brunel, William Patterson, a Bristol shipbuilder, and Henry Richard Guppy, another Bristolian who afterwards did good engineering work in Italy. When completed in 1845, the Great Britain, after being visited by Queen Victoria, took her place beside the Great Western on the Atlantic and made several crossings. Unfortunately, in September 1846 she ran ashore in Dundrum Bay, Co. Down, but was salved a year later. She was refitted as an auxiliary screw ship, and for many years employed on the Australian run. In 1882 she was converted into a sailing ship. Her active service came to an end four years later, when after a severe buffeting off Cape Horn she put into Port Stanley, Falkland Islands, where she became a wool hulk. Up to 1938 at least, she was still so used, an eloquent testimony to the quality of her iron hull and the workmanship of the Bristol shipbuilders.

National Research Council, Canada : Scholarships

The National Research Council, Canada, announces the award for the academic year 1943-44 of 14 fellow. ships of the value of 750 dollars each, 30 studentships of 650 dollars each and 21 bursaries of 250 dollars each. The sixty-five successful candidates for these post-graduate scholarships comprise graduates of fifteen Canadian universities, and they will carry out research work in the ecming year at eleven of these institutions. As a result of war conditions, the fields of science in which the scholarship holders will work are reduced in number as compared with a few years ago. By far the greatest number will work in various branches of chemistry related to the war effort. According to a general classification adopted in announcing the awards, 49 will study chemistry, 6 physics (including one radiology), 4 biochemistry, 2 genetics, and one each biology, mineralogy, mechanical engineering and electrical engineering.

\section{Announcements}

THE following have been elected officers and members of council of the Institution of Electrical Engineers for the year 1943-44: President: Sir A. Stanley Angwin; Vice-Presidents: Mr. T. G. N. Haldane, Dr. E. B. Moullin; Hon. Treasurer: Mr. E. S. Byng; Ordinary Members of Council: Brigadier F. T. Chapman, Mr. J. Hacking, Mr. A. L. Lunn, Dr. J. L. Miller, Mr. J. S. Forrest, Mr. E. C. S. Megaw, and Mr. E. Leete.

WE have received a copy of the revised pamphlet "Photography as an Aid to Scientific Work" from Ilford Ltd., Ilford, London. This gives lists of plates, films and papers suitable for all branches of scientific work, including medicine and surgery, clinical photography and radiography. There are also notes on filters and darkroom safe-lights. 